DOI: $10.5613 /$ rzs.43.2.7

\section{Anthony Pagden \\ The Enlightenment: And Why It Still Matters}

Oxford: Oxford University Press, 2013, 436 str.

Bivši čelnik američke centralne banke Alan Greenspan u svojoj je autobiografiji, objavljenoj prije samoga početka financijske krize, zaključio da je prosvjetiteljstvo zaslužno za pobjedu ideja slobodnog tržišta. Posebno je tada pohvalio tradiciju britanskog prosvjetiteljstva i istaknuo činjenicu da su najslobodnija gospodarstva svijeta ona koja su nasljednici toga intelektualnog miljea: Velika Britanija i SAD, ali i države kao što su Novi Zeland, Hong-Kong ili Singapur. S obzirom na to da se Greenspanov ideološki profil i njegovo dosljedno izbjegavanje reguliranja financijskih tržišta smatraju neposrednim povodom izbijanja svjetske financijske krize, očito je da su ideje prosvjetiteljstva još uvijek vrlo utjecajne.

Britanski povjesničar ideja s UCLA-a Anthony Pagden u svojoj se najnovijoj knjizi The Enlightenment: And Why It Still Matters bavi upravo značenjem prosvjetiteljstva danas. No, za razliku od Greenspana, njega ne zanima toliko utjecaj prosvjetiteljstva na nastanak ekonomskog liberalizma, nego ponajprije na nastanak ideje kozmopolitizma i koncepta građanina svijeta. Dakle, ta knjiga nije klasična analiza povijesti prosvjetiteljstva, a koje su još uvijek prilično česta pojava u suvremenoj znanstvenoj produkciji, i u kojima se vode intenzivne rasprave o ispravnoj interpretaciji glavnih odrednica prosvjetiteljskog projekta. Pagden u toj knjizi ne posvećuje previše vremena određivanju tko bi mogao biti prvi ili ključni mislilac prosvjetiteljstva (kao što to primjerice čini Jonathan Israel s naglašavanjem Spinozine uloge), a čitatelj u njoj neće naći ni odgovor na pitanje o tome kolike su razlike između škotskog i francuskog prosvjetiteljstva (čime se bave istraživači nacionalnih varijanti prosvjetiteljstva). Pagden želi pokazati da su svi oni koji se smatraju modernim, slobodno mislećim pojedincima izravni nasljednici prosvjetiteljskog pokreta, a da su optužbe o prosvjetiteljstvu kao izvoru europskog imperijalizma i uzroku stvaranja bezosjećajnog društva neopravdane.

Pagden pokazuje da je prosvjetiteljstvo zapravo intenziviranje i uobličavanje u smisleni projekt ideja koje su bile prisutne još kod nekih antičkih i renesansnih filozofa. Iako Pagden s neskrivenim zadovoljstvom piše o Voltaireovu izrugivanju biblijskim tekstovima, on i kršćanstvu daje ulogu u razvoju kozmopolitske ideje. Tako on tvrdi da je prosvjetiteljstvo »isključivo europski fenomen [...] koji je mogao izrasti samo u kršćanskom svijetu. Ono je, na neki način, oblik sekulariziranog kršćanstva« (str. 83). Pagdenovu je argumentaciju najlakše razumjeti ako se ta knjiga promatra kao nastavak njegove prethodne knjige Worlds at War: The 2,500-Year Struggle between East and West iz koje su čak preuzeti i neki dijelovi teksta. U 
toj je knjizi Pagden želio pokazati da se sukob Istoka i Zapada može pratiti još od vremena Grčko-perzijskih ratova te da taj sukob (osobito u tom istom dijelu svijeta) traje još i danas. Glavnu ulogu u razlikovanju tih dvaju svjetova odigrali su upravo prosvjetiteljstvo i promjene koje je ono donijelo Zapadu. Pagden u The Enlightenment ocrtava hipotetsku situaciju u kojoj se u Europi nije dogodilo prosvjetiteljstvo i koju je na kraju u cijelosti progutalo Osmansko carstvo. To je situacija koja se, prema Pagdenu, nakon Prvoga svjetskog rata dogodila Bliskom istoku i to upravo zbog izostanka vrijednosne revolucije kroz koju je od 16. stoljeća Europa prolazila. Razlika između utjecaja islama i kršćanstva nije toliko u njihovim izvornim učenjima, jer Pagden navodi da je u oba slučaja riječ o kozmopolitskim religijama, nego je razlika u tome da od početka 13. stoljeća, tj. nakon smrti Ibn Rušda, nije više bilo islamskih filozofa koji bi propitivali religijske dogme. A islamski vjerski vođe napadali su prevođenje tekstova $\mathrm{s}$ grčkog jezika i sve znanje koje nije dolazilo iz Kurana. S druge strane, ideje stoicizma, epikurizma, pa i skepticizma prokrijumčarene su u europski kršćanski svijet te se iz njihova kombiniranja i suprotstavljanja razvila prosvjetiteljska misao. Pagden napose naglašava stoicizam koji je ponudio osnovu za razumijevanje ljudskog društva i stvaranja znanosti o čovjeku. Primjerice, on tvrdi da je Smithov koncept »'nevidljive ruke' [...] izraz stoičke ideje o esencijalnoj harmoničnosti prirodnog svijeta« (str. 62). No, za Pagdena je najvažnije nasljeđe stoicizma u ideji o međupovezanosti cijeloga čovječanstva koju su prihvaćali svi mislioci prosvjetiteljstva.

Pagdenova analiza nastanka prosvjetiteljskog kozmopolitizma upravo je i najznačajniji doprinos knjige. Pagden najprije suprotstavlja Hobbesovo i Grotiusovo prihvaćanje samo jednoga prirodnog prava - onog na samoodržanje i prosvjetiteljsku viziju benignoga kozmopolitskog svijeta. A također i spominje razliku između Rousseauova i Diderotova koncepta opće volje u kojoj Diderotov koncept ima kozmopolitsku dimenziju i obuhvaća sve stanovnike svijeta, dok se Rousseauov odnosi samo na pripadnike jednog društva. Pohvalno je da se Pagden bavi i manje spominjanim autorima, primjerice Raynalom koji je sredinom 18. stoljeća bio jedan od najžešćih kritičara europskog kolonijalizma i ropstva. Pagden s pomoću Raynalova djela, ali i djela drugih putopisaca, prikazuje povećani interes za zemlje Istoka u vrijeme prosvjetiteljstva, što je znatno utjecalo na razvoj kozmopolitizma. Ne samo da je Raynalova Povijest dvije Indije bio prvi pokušaj "pisanja povijesti svijeta kao uistinu globalnog sustava« (str. 220), nego su i promišljanja o dalekim kulturama davala recepte za normativno oblikovanje europskog kozmopolitizma. Analizirajući razvoj Tahitija i Kine, europski su prosvjetitelji došli do istog zaključka. U Kini je, zbog njezina zatvaranja, razvoj zaustavljen te je ona, iako na puno višem stupnju razvoja od Tahitija, postala inertnim društvom poput onoga $\mathrm{s}$ udaljenoga polinezijskog otoka. Prosvjetitelji su zaključili da bi svako zatvaranje 
prema drugima i izostanak miješanja $\mathrm{s}$ drugim kulturama bilo štetno za razvoj civilizacije.

Dakako, najveći dio analize prosvjetiteljskog kozmopolitizma posvećen je Kantovu djelu Prema vječnom miru $\mathrm{u}$ kojem je on ponudio kozmopolitsko pravo i svjetsku federaciju kao rješenja za prevladavanje stalnih ratnih sukoba među nacijama. Pregled razvoja prosvjetiteljske kozmopolitske misli završava Kantovim entuzijastičnim stavom prema Francuskoj revoluciji za čije je izbijanje smatrao kako pokazuje da ideje mogu mijenjati svijet. Pagden zaključuje kako je Kantova ideja kozmopolitizma zaslužna za nastanak međunarodnih organizacija kao što su Liga naroda, Ujedinjeni narodi ili Europska unija. No Pagden propušta elaborirati u kojoj mjeri je nastanak tih organizacija rezultat implementacije Kantove ideje vječnog mira, a koliko su one izraz općeg konsenzusa nakon dvaju svjetskih ratova da se budući ratovi tih dimenzija moraju spriječiti ako se želi izbjeći potpuno uništenje ljudske vrste. Pagden tako citira Mazowerovu knjigu o ideološkim izvorima nastanka Ujedinjenih naroda i izdvaja kantovske vizije kojima se legitimirao nastanak UN-a. Međutim, ne spominje Mazowerovu tvrdnju o različitim idejama koje su bile vodilje UN-ovih osnivača. Među njima je iznimno važna bila i uloga Jana Smutsa, južnoafričkog premijera sklonog imperijalističkim i rasističkim idejama.

Prikazujući pak današnje rasprave o prosvjetiteljstvu, Pagden se drži ponajprije konzervativnih i postmodernističkih kritika prosvjetiteljskog projekta koje pobija naglašavajući empatičku dimenziju prosvjetiteljstva. Šteta je što se Pagden ne bavi i razlikama i polemikama unutar prosvjetiteljskog tabora gdje neki, poput Rifkina, naglašavajući uvođenje ekološke dimenzije, govore o potrebi za stvaranjem »drugog prosvjetiteljstva «. Sama činjenica što se i Habermas, kojeg Pagden izdvaja kao nasljednika kantovskog kozmopolitizma, ali i ovdje spomenuti Greenspan, smatraju baštinicima prosvjetiteljske ideje, govori o svoj složenosti interpretacije prosvjetiteljskog nasljeđa. A sliku još više usložnjava i to da se, kao što je to i Greenspan uočio, i brojna društva Istoka čvrsto drže nekih prosvjetiteljskih vrijednosti.

Bez obzira na te prigovore, Pagdenova je knjiga vrlo intrigantna dopuna udžbeničkim analizama prosvjetiteljskog pokreta. Usprkos svojem snažnom zagovaranju prosvjetiteljstva Pagden pokazuje i izuzetnu sposobnost da čitatelju s pomoću analize tekstova, ali i različitih povijesnih anegdota, približi kako nastanak glavnih ideja prosvjetiteljskog projekta, tako i karaktere njihovih nosilaca. Razmatranje pozicije prosvjetiteljstva kao glavnoga razlikovnog elementa Zapada i Istoka neophodan je pokušaj analize jednoga intelektualnog pokreta $\mathrm{u}$ globalnom kontekstu. No, zbog autorove snažne vjere u isključivo pozitivne posljedice prosvjetiteljskih ideja takvo razmatranje istodobno daje i povod za kritiku Pagdena kao orijentalističkog autora.

$$
\begin{array}{r}
\text { Nikola Petrović } \\
\text { Institut za društvena istraživanja u } \\
\text { Zagrebu }
\end{array}
$$

